\section{Storage of vaccines in general practice}

\author{
S Hunter
}

A successful immunisation programme requires vaccines to be stored continually in conditions that maximise their potency - that is, at low temperatures. Vaccines differ in their sensitivity to adverse storage conditions, and manufacturers offer guidelines for storage temperatures, which should be observed to guarantee potency. Stimulated by the introduction of the measles, mumps, and rubella vaccine and the publication of the Department of Health and Social Security's report on immunisation against infectious diseases, 'I examined the use and storage of vaccines in my practice. My findings prompted me to examine the storage of vaccines in other practices.

\section{Methods and results}

I distributed a questionnaire among nurses on two courses for practice nurses. They worked in 36 different practices in south Hampshire and Dorset. The box gives the results of the 36 questionnaires.

\section{Discussion}

Manufacturers recommend storage conditions for all of their vaccines. If vaccines are stored outside the specified temperature range they may remain potent, but this cannot be guaranteed. No vaccines should be frozen, ' and in general they should be stored at $2-8^{\circ} \mathrm{C}$. (Polio vaccine should be stored at $0-4^{\circ} \mathrm{C}$.) In this study nurses in most (33/36) general practices did not know at what temperature their refrigerators were operating. An inefficient fridge or one with an inadequately adjusted thermostat may operate at close to room temperature. Conversely, the contents of a refrigerator may freeze if the thermostat has not been calibrated with a thermometer and the fridge has been defrosted recently or not opened for a long time. Therefore, practice nurses cannot be sure whether the vaccines they use are potent and whether they will provide adequate protection against lifethreatening diseases.

A specialised refrigerator (for example, an Electrolux RA $122(\mathrm{H})$ ) has a thermostat set between $2^{\circ}$ and $6^{\circ} \mathrm{C}$ and an external "safe zone" temperature gauge. This makes storage conditions far easier to control than those of domestic refrigerators, although a thermometer is still recommended to ensure correct calibration. In all, 33 of the practices in this study used a basic domestic refrigerator.

To maintain their efficiency refrigerators need to be defrosted regularly. Vaccines may deteriorate while this is being done if they are kept at room temperature for several hours, as was the procedure in 11 practices.

Sixteen practice nurses kept phials containing multiple doses of tetanus for more than one session after opening, and six kept them for up to one month. Once a phial has been opened there is a risk of contamination of the vaccine and destruction of its potency. The joint committee on vaccination and immunisation' and the manufacturers have strict guidelines on this. The use of phials containing single doses would avoid this problem.

\section{Results of questionnaires by 36 practice} nurses

(1) Do you keep a thermometer in your fridge? Yes

No

(2) What type of fridge do you use? Domestic Specialised with "safe zone" gauge

One of the specialised fridges contained a thermometer)

(3) What do you do with vaccines when you are defrosting the fridge?

\section{Throw vaccines away}

Use other fridge or ice box

Put them to one side and then return to fridge

(4) How long do you keep phials containing multiple doses of tetanus vaccine once opened? One session only

Between one session and one week

Between one week and one month

Use phials containing single doses Surgery, 12 Salisbury Road, Totton, Hampshire SO4 3PY.
(5) Do you give your patients vaccines to store at home? Yes No

If "yes," which vaccines do you give patients to store at home?

$\begin{array}{lr}\text { Typhoid } & 7 / 18 \\ \text { Cholera } & 7 / 18 \\ \text { Hepatitis B } & 14 / 18 \\ \text { Influenza } & 3 / 18\end{array}$

Care of vaccines would probably be worse if they were kept by patients and stored in their refrigerators. Yet 18 practice nurses gave patients some vaccines to store at home. Hepatitis B vaccine was the one most commonly stored in patients' refrigerators. This probably reflects the inconvenience to practice nurses of storing the third dose for between six and 12 months if the whole course was originally obtained on one prescription. There is great potential for damage to the vaccine if it is stored for six to 12 months in inadequate conditions, and this may be one reason for the poor antibody response that is sometimes seen.

Guidelines for storing vaccines are not often observed. Yet storage conditions that preserve the potency of vaccines may be achieved simply and cheaply. The following recommendations can be made:

- Every fridge should contain a maximum-minimum thermometer

- Read the temperature twice a day and make adjustments to the temperature control of the fridge when necessary

- Store vaccines with the thermometer in the middle of the fridge

- Keep the storage of other items in the fridge to a minimum: this avoids repeated opening of the door of the fridge

- Defrost the fridge regularly; while doing this store 
the vaccines in another fridge or in a cool box containing ice blocks

- Ideally use a fridge designed for storing vaccines. Such fridges have preset thermostats and external temperature gauges

- When possible use phials containing single doses, and if these are not available discard opened phials containing multiple doses at the end of a session.

The inadequate storage conditions for vaccines reported in this study put the success of an immunisa- tion programme at risk. The use of low potency vaccines wastes time and money and is potentially dangerous. Simple measures can be taken to guarantee the potency of vaccines and the success of immunisation.

I thank Mrs Angela Palmer and Mrs Gill Nicholson for their help in distributing the questionnaires.

1 DHSS Joint Committee on Vaccination and Immunisation. Immunisation against infectious disease. London: HMSO, 1988.

\section{BOOKS RECEIVED}

\section{Dermatolog}

Acne. W J Cunliffe. Series editor $\mathrm{R}$ Marks. (Pp viii +391 ; figs and colour plates; £65.) London: Dunitz, 1989. ISBN 0-948269-39-1.

Models in Dermatology. Vol 4. Volume and series editors $\mathrm{H}$ I Maibach, $\mathrm{N}$ J Lowe. (Pp x+297; figs; £168.20.) Basle: Karger, 1989. Distributed by John Wiley and Sons. ISBN 3-8055-4761-7.

\section{Diabetes}

Diabetes Complicating Pregnancy: The foslin Clinic Method. Ed J W Hare. (Pp xii+194; figs; $\$ 49.50$.) New York: Liss, 1989. Distributed by John Wiley and Sons. ISBN 0-8451-4268-2.

Molecular and Cellular Biology of Diabetes Mellitus. Vol 1. "Insulin Diabetes Mellitus. Vol 1. "Insulin
Secretion." Ed B Draznin, S Melmed, Secretion." Ed B Draznin, S Melmed, D LeRoith. (Pp ix +172 ; figs; $\$ 53$.)
New York: Liss, 1989. Distributed by Jown Wiley and Sons. ISBN 0-845IJohn W.

Molecular and Cellular Biology of Diabetes Mellitus. Vol 2. "Insulin Action." Ed B Draznin, S Melmed, D LeRoith.(Pp ix +231; figs; \$53.) New York: Liss, 1989. Distributed by John Wiley and Sons. ISBN 0-8451-4258-5. Molecular and Cellular Biology of Diabetes Mellitus. Vol 3. "Complications of Diabetes Mellitus." Ed B Draznin, S Melmed, D LeRoith. (Pp $\mathrm{x}+168$; figs; $\$ 53$.) New York: Liss, 1989. ISBN 0-845I-4359-3.

\section{General practice}

Oxford General Practice Series. No 15 "Psychological Problems in General Practice." A C Markus, C M Parkes, P
Tomson, M Johnston. (Pp xiv +406; Tomson, $M$ Johnston. (Pp xiv +406 ;
figs; 117.50 paperback.) Oxford: figs; 117.50 paperback.) Oxford: 0-19-261529-7.

\section{Laboratory medicine}

Advances in Biotechnological Processes. Vol 11. "Monoclonal Antibodies: Production and Application." Volume and series editor A Mizrahi. (Pp xv+ 417; figs; \$96.) New York: Liss, 1989. Distributed by John Wiley and Sons. ISBN 0-8451-3210-5.

A Guide to Laboratory Investigations. M F McGhee. (Pp x+92; 26.50 paperback.) Oxford: Radcliffe Medica Press, 1989. ISBN 1-870905-15-6.

Protein Blotting: Methodology, Research and Diagnostic Applications. Ed B A Baldo, E R Tovey. (Pp vii + 168; figs; £50.90.) Basle: Karger 1989. Distributed by John Wiley and Sons. ISBN 3-8055-4881-8.

\section{Medical Ethic}

Christian Ethics in Health Care: a Source Book for Christian Doctors, Nurses and Other Health Care Professionals. J Wilkinson. (Pp xiv +510 ; Press, 1989. ISBN 0-905312-35-X.

\section{Microbiology}

Diagnostic Clinical Microbiologv: a Benchtop Perspective. S Fessia,
$P$ Fawcett, C Macvaugh, S Ryan. (Pp xiii +221; figs; $£ 12.50$ paperback. Philadelphia: Saunders, 1988. Distributed by Harcourt Brace Jovanovich. ISBN 0-7216-2326-3.

Septicaemia and Endocarditis; Clinical and Microbiological Aspects. Ed D Shanson. (Pp x+177; figs; £25.) Oxford: Oxford University Press, 1989. ISBN 0-19-261507-6.

\section{Nephrolog}

Nephrology Today. Vol 2. "Management of Common Problems in Rena Disease," Ed H G Preuss. 06; figs; 27 . Preuss. (Pp viii 06; figs; 227.$)$ London; Collie 396520-7.

\section{Neurology}

mplications of the Blood-Brain Barrier and Its Manipulation. Vol 2. "Clinical Aspects." Ed E A Neuwelt. (Pp xxx + 633; figs and colour plates; $\$ 100$.) New York: Plenum, 1989. ISBN 0-306$42637-4$.

Neuroembryology: Cellular and Molecular Approaches. Ed J de Vellis, G Ciment, J Lauder. (Pp x+537; figs buted by John Wiley and Sons. ISBN $0-8451-4273-9$.

Neurological Disease and Therapy. Vo 2. "Medical Therapy of Acute Stroke." Ed M Fisher. Series editor W C Koller. (Pp xii + 295; figs; $\$ 83.50$. New York: Dekker, 1989. ISBN 08247-7870-7.

Neurology and Psychiatry; a Meeting of Minds. Ed J Mueller. (Pp xiv +290 figs; colour plates; £101.90.) Basel: Karger, 1989. Distributed by Joh Wiley and Sons. ISBN 3-8055-4712-9. Neuromethods. 7. "Lipids and Relate Compounds." Ed A A Boulton, G Baker, L A Horrocks. (Pp xx +343 figs; $\$ 74.50$.) New Jersey: Human Press, 1988. ISBN 0-89603-124-1.

Reducing the Risk of Alzheimer's. M A Weiner. (Pp 176; $£ 5.95$ paperback.) Bath: Gateway Books, 1989. ISBN 0 946551-53-7.

Topics in Neurosurgery. "Neurosurgical and Medical Management of Pain Trigeminal Neuralgia, Chronic Pain and Cancer Pain." Ed R Brisman. (Pp xi+205; figs; $\{53.25$.) Boston: $\mathrm{x} 1+205$; figs; $\{53.25$.) Boston:
Kluwer, 1989. Distributed by MTP Rluwer, 1989. Distributed

\section{Nutrition}

Clinical Nutrition in Paediatric Disorders. D Bentley, $M$ Lawson. (Pp xii +332 ; figs; £42.50.) London: Baillière Tindall, 1988. Distributed by Harcourt Brace Jovanovich. ISBN 07020-1245-9.

\section{Obstetrics and gynaecology}

The BMA Family Doctor Guides. "Menopause: Treating the Symptoms." P Bromwich. Series ditor T Smith. (Pp 95; figs; $£ 2.99$ paperback.) London: Equation in association with the British Medica Association, 1989. ISBN 1-85336051-1.

The Encyclopedia of Pregnancy and
Birth. J Balaskas, Y Gordon. YPp 352; figs; $\{9.95$ paperback.) London: Macdonald/Orbis, 1989. ISBN 0-356 15323-1.

\section{Oncology}

Atlas of Germ Cell Tumours. G K Jacobsen, A Talerman. (Pp 220 colour plates; DKK 620 . Copenhagen: Munksgaard, 1989 ISBN 87-16-06490-9.

Genes and Signal Transduction in Mult stage Carcinogenesis. Ed N H Colburn. Pp xiii + 462; figs; \$150.) New York: Dekker, 1989. ISBN 0-8247-7996-7.

Prostaglandins, Leukotrienes, and Cancer. "Carcinogenesis and Dietar Fat." Ed S Abraham. Series editors $\mathrm{K}$ $\checkmark$ Honn, L J Marnett. (Pp xvii +492; figs; $\{77$.$) Boston: Kluwer, 1989$
Distributed by MTP Press. ISBN 0 7923-0117-X

Orthopaedics

Frontiers in Fracture Management. Ed Pp viii 184; figs; 149.95 .) London: Dunitz, 1989. ISBN 0-948269-37-5.

Paediatrics

Bristol Language Development Scales Manual. M Gutfreund, M Harrison, $G$ Wells. (Pp vi +122 ; 18 paperback. Complete set, including a pack of record forms and a pack of therapy planners, 35 + VAT W Windsor: NFER-Nelson, 1989.

British Paediatric Association Manual on Infections and Immunizations in Children. A Nicoll, P Rudd. (Pp xxy 349; $£ 9.95$ paperback.) Oxford: Oxford University Press, 1989. ISBN 0-19-261785-0.

The Don't Spoil Your Body Book. C Rayner. Illustrated by Tony King. ( $P$ 48; figs; $£ 4.95$ paperback.) London: Bodley Head, 1989. ISBN 0-370 31269-4.

Modern Problems in Paediutrics. Vol 4. "Congenital Diaphragmatic Hernia." Ed P Puri. Series editors Falkner, N Kretchmer, E Rossi. (Pp viii 161: figs: 554.60 ) Basle: Karger, 1989. Distributed by John Wiley and Sons. ISBN 3-8055-4807-9.

Sudden Infant Death Syndrome: Medical Aspects and Psychological Management. Ed J L Culbertson, H F Krous, R D Bendell. (Pp xix +264 ; figs; £29.95.) London: Arnold, 1989 ISBN 0-340-49381-6.

Textbook of Paediatric Anaesthetic Practice. Ed E Sumner, D J Hatch. Pp xii+603; figs; $£ 37.50$.) London: Baillière Tindall, 1989. Distributed by Harcourt Brace Jovanovich. ISBN 07020-1336-6.

\section{Pharmacology - Clinical}

Pharmacology and the Skin. Vol 2. "Nonsteroidal Anti-Inflammatory Drugs." Ed N J Lowe, C N Hensby. Series editors B Shroot, H Schaefer. Pp ix +158; figs; 167.80 .) Basle: Karger, 1989. Distributed by John Wiley and Sons. ISBN 3-8055-4898-2. Progress in Basic and Clinical Pharmacology Vol 2. "Clinical Aspects of

Calcium Entry Blockers." Ed P A van Zwieten. Series editors P Lomax, E S Vesell. (Pp xii +200 ; figs; $£ 83.70$. Basle: Karger, 1989. Distributed by John Wiley and Sons. ISBN 3-8055-4858-3.

Prostaglandins in Clinical Practice. Ed W D Watkins, M B Peterson, J R Fletcher. (Pp xii + 263; figs; $\$ 122.50$.) New York: Raven Press, 1989. ISBN 0-88167-489-3.

The Receptors. "The Serotonin Receptors." Ed E Sanders-Bush. Series editor D B Bylund. (Pp xvi + 388; figs; $\$ 79.50$.) New Jersey: The Human
Press, 1989. ISBN 0-89603-142-X.

\section{Psychiatry}

The BMA Family Doctor Guides. "Depression." G Wilkinson. Series editor T Smith. (Pp 96; figs; $£ 2.99$ paperback.) London: Equation in association with the British Medical Association, 1989. ISBN 1-85336110-0.

Depression and Mania: Modern Lithium Therapy. Reprint. Ed F N Johnson. (Pp xviii + 281; figs; $£ 25$ paperback.) Oxford: IRL Press, 1989. ISBN 185221-174-1

$M C Q$ s for the MRCPsych. Part II. M Levi. (Pp x+85; $£ 5.25$ paperback.) by MTP Press. ISBN 0-7462-0093-5.

\section{Psychology}

The Healing Brain: a Radical New Approach to Health Care. R Ornstein, D Sobel. (Pp 301; 16.99 paperback.) London: Macmillan, 1989. ISBN 0- 